\title{
Genetic diversity of rhizobia nodulating Trifolium ambiguum in North America
}

\author{
P. Seguin, P.H. Graham, C.C. Sheaffer, N.J. Ehlke, and M.P. Russelle
}

\begin{abstract}
Kura clover (Trifolium ambiguum M.B.) is a persistent rhizomatous forage legume, whose use in the U.S.A. is limited by establishment difficulties in part attributable to nodulation problems. In this study, soil was collected from established stands of Kura clover growing in 9 diverse North American environments. Rhizobia were plant-trapped using Kura clover cv. Endura as host, then rhizobia from nodules fingerprinted using BOX-PCR. The diversity of isolates from North America was then contrasted to that of rhizobia from a single Caucasian environment (Russia), the center of origin for this species. Populations were characterized using clustering methods, and genetic diversity estimated using the Shannon-Weaver diversity index. The genetic diversity of the North American populations was extremely limited, all isolates being closely related to two of the strains found in a locally available commercial inoculant. In contrast, Russian isolates formed a distinct cluster with significant internal genetic diversity. Genetic diversity indices for the North American and Russian populations were 3.5 and 10.76, respectively. The implication of this and other studies is that Kura clover is highly specific in Rhizobium requirement. If the performance of this legume in the U.S.A. is to be improved, either by modifying current establishment practices or plant breeding, it is essential that these studies be paralleled by more collections and evaluation of rhizobia from its center of origin, given the extremely limited diversity of rhizobia found in North America.
\end{abstract}

Key words: genetic diversity, rhizobia, Kura clover, BOX-PCR.

Résumé : Le trèfle Kura (Trifolium ambiguum M.B.) est une légumineuse de fourrage persistente à rhizome, dont l'usage aux États-Unis est restreint par des difficultés d'implantation attribuables en partie à des problèmes de nodulation. Dans l'étude présente, de la terre fut prélevée de peuplements établis de trèfle Kura poussant dans neuf environnement nord-américains distincts. Les rhizobiums furent capturés par le cultivar Endura du trèfle Kura en tant qu'hôte, puis les empreintes génétiques des rhizobiums des nodules furent prises par BOX-PCR. La diversité des isolats nordaméricains fut alors contrastée avec celle de rhizobiums provenant d'un environnement caucasien unique (Russie), le centre d'origine de cette espèce. Les populations furent caractérisées par des méthodes de regroupement et l'indice de diversité Shannon-Weaver fut employé pour estimer la diversité génétique. La diversité génétique des populations nordaméricaines était extrêmement limitée, tous les isolats étant fortement apparentées à deux des souches retrouvées dans des incoculums commerciaux locaux. En revanche, les isolats russes ont formé un ensemble distinct pourvu d'une diversité interne appréciable. Les indices de diversité génétique des populations nord-américaines et russes étaient de 3,5 et 10,76, respectivement. La portée de cette constatation et d'autres études est que le trèfle Kura serait hautement spécifique dans ses besoins en Rhizobium. Si la performance de cette légumineuse aux États-Unis doit être améliorée, soit en modifiant les pratiques d'implantation actuelles ou soit par croisement de plants, il est essentiel que ces études soient mises en parallèle avec d'avantage de prélèvements et d'évaluations de rhizobiums provenant de leur centre d'origine, vu la diversité extrêmement limitée des rhizobiums qu'on retrouve en Amérique du Nord.

Mots clés : diversité génétique, rhizobiums, trèfle Kura, BOX-PCR.

[Traduit par la Rédaction]

Kura clover is an exceptionally persistent rhizomatous legume that produces high quality forage. These characteristics have generated interest in using this plant in permanent pastures and for soil conservation in North America and
New Zealand (Taylor and Smith 1998), but establishment problems currently limit widespread adoption. While some of this problem is the result of low initial herbage:root ratio, rendering the plant highly susceptible to competition

Received July 17, 2000. Revision received October 2, 2000. Accepted October 3, 2000. Published on the NRC Research Press web site on December 20, 2000.

P. Seguin, ${ }^{1}$ C.C. Sheaffer, and N.J. Ehlke. Department of Agronomy and Plant Genetics, University of Minnesota, 1991 Buford Circle, 411 Borlaug Hall, St. Paul, MN 55108-6026, U.S.A.

P.H. Graham. ${ }^{2}$ Department of Soil, Water, and Climate, University of Minnesota, 1991 Buford Circle, St. Paul, MN 55108-6028, U.S.A. M.P. Russelle. USDA-ARS, U.S. Dairy Forage Research Center (MN cluster) and Department of Soil, Water, and Climate, University of Minnesota, 1991 Buford Circle, St. Paul, MN 55108-6028, U.S.A.

${ }^{1}$ Present address: Plant Science Department, McGill University, 21111 Lakeshore Rd., Ste. Anne-de-Bellevue, QC H9X 3V9, Canada.

${ }^{2}$ Author to whom all correspondence should be addressed (e-mail: pgraham@soils.umn.edu). 
(Genrich et al. 1998; Seguin et al. 1999); initial growth may also be N-limited due to the low nitrogen fixation achieved with the rhizobial strains currently in use (Seguin 2000).

Kura clover is highly specific in rhizobial requirement, and does not nodulate effectively with rhizobia from other Trifolium species (Parker and Allen 1952). Inoculation is recommended, as few soils outside its center of origin in the Caucasus contain effective indigenous rhizobia (Elliot et al. 1998; Seguin 2000). Even when inoculated, however, Kura clover is likely to have a very low $\mathrm{N}_{2}$ fixing ability in the establishment year. This is due to a delayed nodulation that often makes initial growth N-limited. Seguin (2000) in Minnesota, reported a seeding year $\mathrm{N}_{2}$ fixation in commercially inoculated Kura clover of only $17 \mathrm{~kg} \mathrm{~N} \cdot \mathrm{ha}^{-1}$, with $25 \%$ of $\mathrm{N}$ derived from the atmosphere. In New Zealand, Pryor et al. (1998) reported that a strain isolated locally from fields initially inoculated with commercial inoculant, greatly improved the establishment of oversown Kura clover. They reported individual plant mass 3 times greater 13 months after seeding when inoculated with this newly isolated rhizobial strain (ICC148) than with the strain currently used in New Zealand (ICC105 = UMR6015). Identification and selection of highly efficient, locally adapted strains, which have established in soil after introduction of the inoculated host plant, is therefore possible. This approach has been used successfully with other species (e.g., Santos et al. 1999), but the chances for success may be limited where the host is highly specific in its Rhizobium requirements.

To determine whether growth of Kura clover in soils from different areas of North America can lead to the establishment and persistence of diverse rhizobia, we examined the rhizobia associated with Kura clover in nine North American soils using BOX-PCR (Rademaker and De Bruijn 1997), and compared this to rhizobia obtained from a single soil sample collected in Russia, the center of origin for this species.

Description of the environments sampled is presented in Table 1. Soils were distinguished according to stand age, soil type, and soil fertility status. MPN (Most Probable Number) counts were undertaken using Kura clover as trap host, and according to Somasegaran and Hoben (1994). At each location, soil was collected from at least 12 areas of established Kura clover stands with soil probes used to collect samples down to a depth of $20 \mathrm{~cm}$, discarding the top $2 \mathrm{~cm}$. Kura clover seeds (cv. Endura) were surface sterilized and planted in Leonard jar units (Somasegaran and Hoben 1994). Three days after planting, $10 \mathrm{~mL}$ of a $10^{-1}$ dilution of soil from each location was applied to each of 20 seedlings. Plants were then grown for two months as described by Montealegre et al. (1995). From each set of plants inoculated with a given soil, 30 nodules were randomly collected and surface-sterilized, and individually crushed on yeast mannitol (YM) agar plates (Somasegaran and Hoben 1994). After 5 days of growth, single colonies were transferred to YM broth, grown for 3 days, then mixed with equal volume of $30 \%$ glycerol, and stored at $-70^{\circ} \mathrm{C}$. The source and description of reference strains of Rhizobium used in this study are listed in Table 2.

The BOX-PCR protocol of Rademaker and De Bruijn (1997) with BoxA1R (5'-CTACGGCAAGGCGACGCTGACG-3') (LifeTechnologies, Grand Island, N.Y.) as primer was used for genomic fingerprinting of pure liquid cultures of Rhizobium. Rhizobial cells were prepared as described by Rademaker and De Bruijn (1997), with $2 \mu \mathrm{L}$ of appropriate cell culture used in each reaction mix. PCR was carried using a PTC-100 Thermocycler (MJ Research, Waltham, Mass.), with the PCR product then stored at $-20^{\circ} \mathrm{C}$. Agarose gel electrophoresis was performed using $10 \mu \mathrm{L}$ of the PCR product. One Kb ladder (Sigma, St. Louis, Mo.) was used as size standard and loaded at least twice per gel. Gels were stained with ethidium bromide and gel images stored as TIFF files using a video camera image system (Fotodyne, Hartland, Wis.).

Fingerprint profiles (Fig. 1) were analyzed using BioNumeric software (v. 1.5, Applied Maths, Kortrijk, Belgium) with the band positions in each gel normalized relative to specific bands in the $1 \mathrm{~Kb}$ reference ladder, and with a clear band present in most isolate profiles used as an internal reference. Similarities between profiles were then calculated for bands in the range of 300-1650 bp in length using the UPGMA, unweighted pair group method with arithmetic averages, and the data transformed using the principal component option within the Bionumeric program. Significance of the groups identified were then determined using the MANOVA (multivariate analysis of variance) option in BioNumeric. Genetic diversity within groups identified during the MANOVA was determined using the ShannonWeaver diversity index $(H)$ using the equation:

[1] $\quad H=-\sum_{i=1}^{k} p i \times \ln p i$

where $k$ is the number of band classes, and $p i$ is the frequency of isolates in the $i$ th class (Goodwin et al. 1992).

BOX-PCR fingerprinting successfully discriminated Kura clover rhizobial isolates and strains from reference strains belonging to other rhizobial species (e.g., Rhizobium etli, $R$. tropici, and Sinorhizobium meliloti), Kura clover rhizobia being more closely related to UMR6906, the type strain for $R$. l. bv. trifolii to which Kura clover rhizobia putatively belongs, than these other species. Relative similarity between Kura clover rhizobia and UMR6906 was, however, low.

Three main groups were identified among Kura clover rhizobial strains and isolates using principal component analysis (Fig. 2). Grouping was demonstrated by MANOVA to be statistically significant $(P<0.05)$. One group contained all North American isolates and the inoculant strains UMR6013, UMR6015, and ICC148, while a second group included all of the Russian isolates. A third, smaller group, contained only four inoculant strains used in North America (UMR6014, UMR6019, RP-119-2, and RP-119-4). The genetic diversity as determined by the Shannon-Weaver diversity index was significantly lower in the North American group than in the Russian one, being of 3.51 and 10.76, respectively. Genetic diversity in the North American population was extremely low despite the range of environments sampled. These included a range of soil types and soil fertility levels, and stand ages up to 17 years (Table 1). In other cases where rhizobia have been introduced as inoculants into areas where they were not indigenous, substantial diversity among the nodule population was generated quite rapidly 
Table 1. Description of sites used for isolation of Kura clover rhizobia.

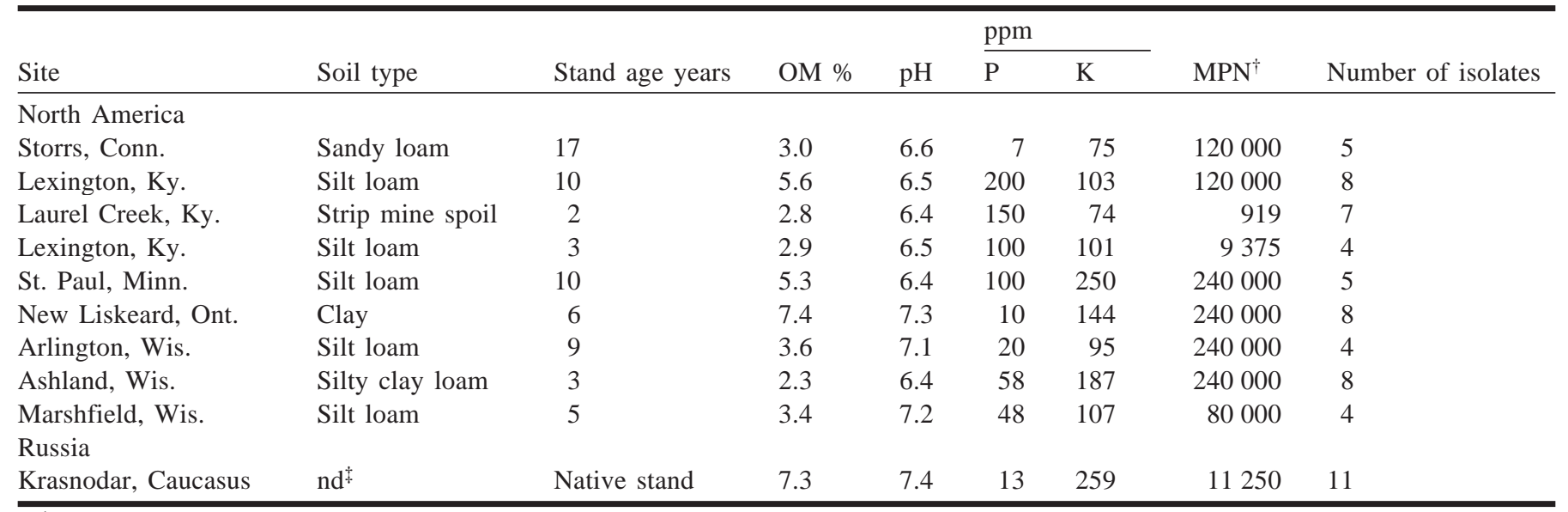

${ }^{\dagger}$ MPN, Most Probable Number of Kura clover rhizobia per gram of soil.

${ }^{\ddagger}$ nd, not determined.

Table 2. Description of rhizobial strains used in this study.

\begin{tabular}{|c|c|c|c|}
\hline Strain & Synonym(s) & Origin/source & Notes \\
\hline UMR1632 & & $\mathrm{UMR} \dagger$ & Rhizobium etli \\
\hline UMR1899 & & UMR & R. tropici \\
\hline UMR6013 & $162 \mathrm{C} 14$ & Liphatec & Part of Liphatec Kura clover inoculant \\
\hline UMR6014 & $162 \mathrm{C} 11$ & Liphatec & Part of Liphatec Kura clover inoculant \\
\hline UMR6015 & $162 \mathrm{C} 13, \mathrm{CC} 283 \mathrm{~b}, \mathrm{ICC} 105$ & Liphatec & $\begin{array}{l}\text { Part of Liphatec Kura clover inoculant, Inoculant strain used for } \\
\text { hexaploid Kura clover in New Zealand }\end{array}$ \\
\hline UMR6906 & TA1 & UMR & R. leguminosarum bv trifolii type strain \\
\hline ICC 148 & & $\begin{array}{l}\text { Ag-Research } \\
\text { New Zealand }\end{array}$ & Superior Kura clover isolate from field in New Zealand \\
\hline RP-119-2 & & Urbana & Part of Urbana Kura clover inoculant \\
\hline RP-119-4 & & Urbana & Part of Urbana Kura clover inoculant \\
\hline
\end{tabular}

${ }^{\dagger}$ UMR, University of Minnesota Rhizobium laboratory.

(e.g., Sullivan et al. 1995). Build-up in diversity in a population of rhizobia results from aerial or seed-borne contamination, mutation, conjugation, and transduction events (Martinez et al. 1990). Clearly, this did not happen with Kura clover rhizobia, probably because of the extreme specificity of the host.

All North American Kura clover rhizobial isolates we studied were closely related to UMR6013 and UMR6015, two of the strains found in a locally available commercial inoculant. Other strains are included in commercial inoculants but do not appear to compete or persist well in the field. The success of strains UMR6013 and UMR6015 was indicated not only by their dominance across a range of North American environments, but also by the high Kura clover rhizobial population size shown in MPN counts (i.e., average of 143366 rhizobia per gram of soil) (Table 1).

The lack of genetic diversity among our North American isolates does not exclude the possibility of finding a superior isolate adapted to North American conditions. Similarity in the BOX-PCR fingerprint profiles between UMR6015 and ICC148 (Fig. 1) indicate that genetic diversity as determined by this method is not likely related to variation in symbiotic competence or suitability for inoculant use. This was also reported in similar studies done with other species (e.g., Gonzales-Andres and Ortiz 1998). However, greater chance for improvements should come from further isolation and evaluation of rhizobial isolates from the center of origin of this species, given the prevalence of a much greater genetic diversity.

\section{Acknowledgements}

We thank K.A. Albrecht (University of Wisconsin), D.W. Allinson (University of Connecticut), J. Johnson (New Liskeard, Ont., Canada), and N.L. Taylor (University of Kentucky), for supplying soil samples used for bacterial isolation, and H.N. Pryor (AgResearch, Invermay, New Zealand), R.S. Smith (Liphatec, Milwaukee, Wis.), and T. Wacek (Urbana, St. Joseph, Mo.) for supplying rhizobial strains. The senior author also appreciates financial support from the University of Minnesota through a doctoral dissertation fellowship. This research was supported in part by the Minnesota Agricultural Experiment Station. 
Fig. 1. BoxA1R-PCR fingerprinting of Kura clover rhizobial strains and isolates from North America. Lanes 1 to 8 , isolates from a 10 year old stand in Lexington, Ky.; lanes 9 and 10, isolates from a 2-year-old stand established on a strip mine spoil in Laurel Creek, Ky.; lanes 11 to 14, isolates from a 3-year-old stand in Lexington, Ky.; lanes 15 to 20, inoculant strains ICC148, UMR6014,

UMR6013, UMR6015, RP119-2, and RP119-4; lane 21, strain UMR6906 (R. l. bv. trifolii type strain); lanes 22 to 24, isolates from a 6-year-old stand in New Liskeard, Ont.; lanes 25 to 27, isolates from a 17-year-old stand in Storrs, Conn.; M, 1 Kb molecular weight marker.

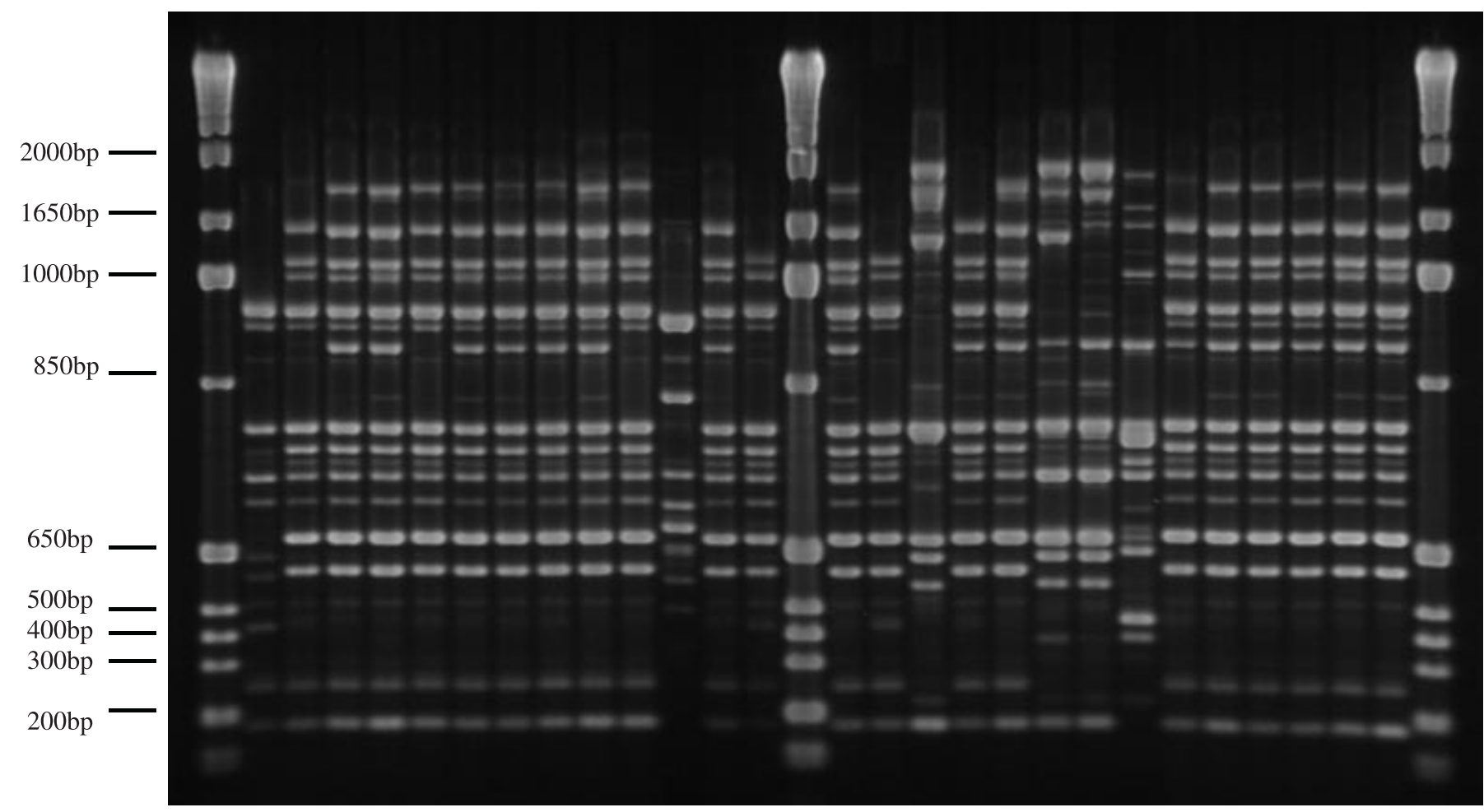

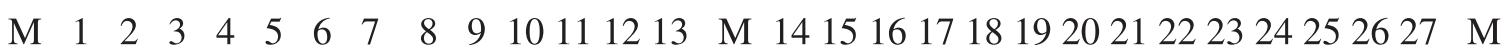

Fig. 2. Two-dimensional plot of principal component analysis generated from Box-PCR fingerprint profiles of Kura clover rhizobial strains and isolates from 9 North American and 1 Russian locations. Grouping was statistically significant as verified by MANOVA $(P<0.05) . H=$ genetic diversity index.

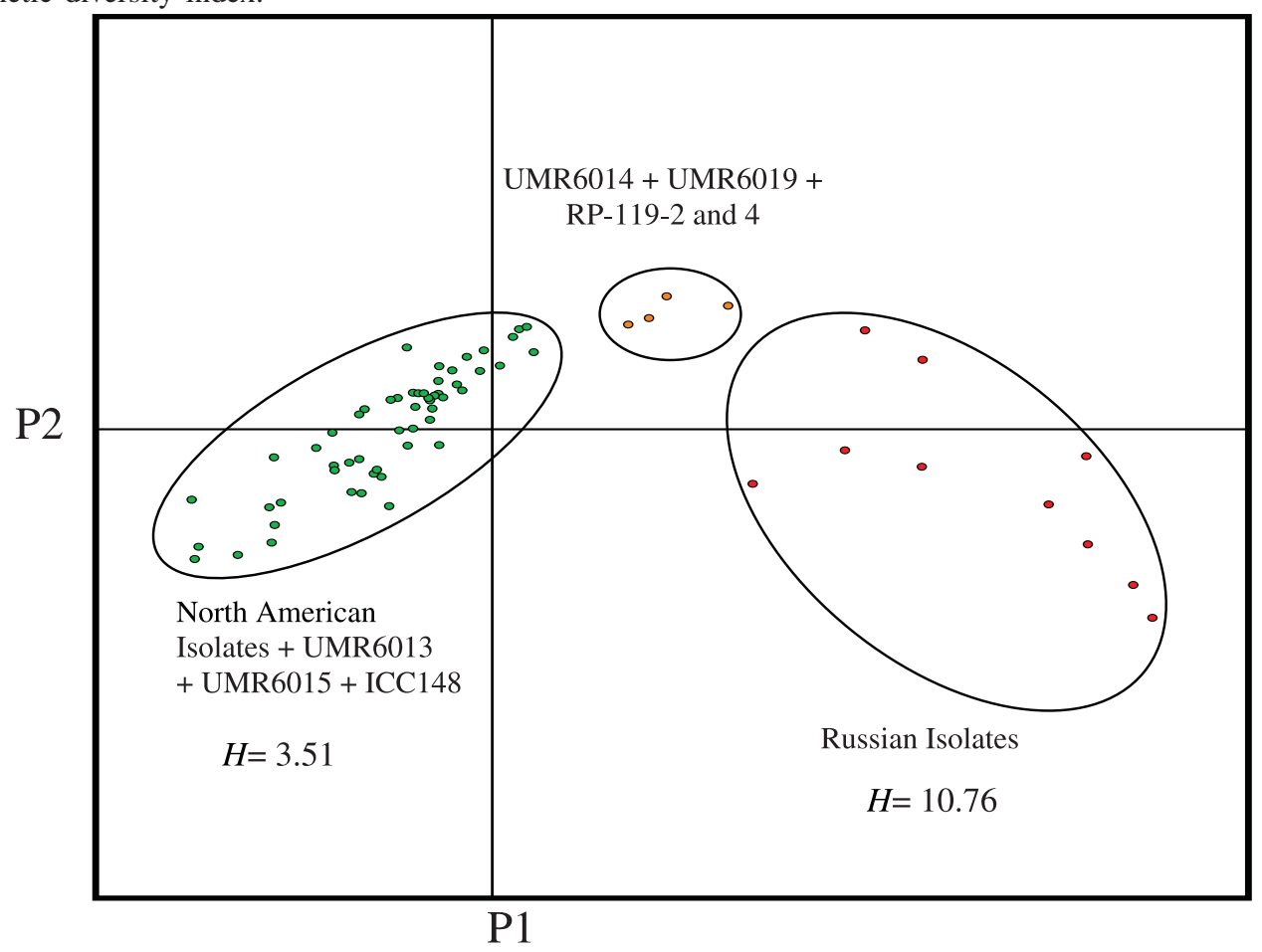




\section{References}

Elliot, R.M., McIntyre, H.J., Challis, B.C., Pryor, H.N., Lowther, W.L., and Ronson, C.W. 1998. Rhizobium issues affecting the contribution of Caucasian clover to New Zealand pastoral agriculture. Proc. N. Z. Grassl. Assoc. 60: 207-211.

Genrich, K.C., Sheaffer, C.C., and Ehlke, N.J. 1998. Kura clover growth and development during the seeding year. Crop Sci. 38: 735-741.

Gonzales-Andres, F., and Ortiz, J.M. 1998. Biodiversity of rhizobia nodulating Genista monspessulana and Genista linifolia in Spain. N. Z. J. Agric. Res. 41: 585-594.

Goodwin, S.B., Allard, R.W., Hardy, S.A., and Webster, R.K. 1992. Hierarchical structure of pathogenic variation among Rhynchosporium secalis populations in Idaho and Oregon. Can. J. Bot. 70: 810-817.

Martinez, E., Romero, D., and Palacios, R. 1990. The Rhizobium genome. Crit. Rev. Plant Sci. 9: 59-93.

Montealegre, C., Graham, P.H., and Kipe-Nolt, J.A. 1995. Preference in the nodulation of Phaseolus vulgaris cultivar RAB39. Can. J. Microbiol. 41: 992-998.

Parker, D.T., and Allen, O.N. 1952. The nodulation status of Trifolium ambiguum. Proc. Soil Sci. Soc. Am. 16: 350-353.

Pryor, H.N., Lowther, W.L., McIntyre, H.J., and Ronson, C.W. 1998. An inoculant Rhizobium strain for improved establishment and growth of hexaploid Caucasian clover (Trifolium ambiguum). N. Z. J. Agric. Res. 41: 179-189.

Rademaker, J.L.W., and De Bruijn, F.J. 1997. Characterization and classification of microbes by Rep-PCR genomic fingerprinting and computer-assisted pattern analysis. In DNA markers: Protocols, applications and overviews. Edited by G. Caetano-Anolles and P.M. Gresshoff. John Wiley \& Sons, Inc., New York. pp. 151-171.

Santos, M.A., Vargas, M.A.T., and Hungria, M. 1999. Characterization of soybean Bradyrhizobium strains adapted to the Brazilian savannas. FEMS Microbiol. Ecol. 30: 261-272.

Seguin, P. 2000. Quantification and characterization of Kura clover (Trifolium ambiguum M.B.) dinitrogen fixation. Ph.D. thesis, University of Minnesota, St-Paul, Minn.

Seguin, P, Sheaffer, C.C., Ehlke, N.J., and Becker, R.L. 1999. Kura clover establishment methods. J. Prod. Agric. 12: 483-487.

Somasegaran, P., and Hoben, H.J. 1994. Handbook for rhizobia. Springer-Verlag, New York.

Sullivan, J.T., Patrick, H.N., Lowther, W.L., Scott, D.B., and Ronson, C.W. 1995. Nodulating strains of Rhizobium loti arise through chromosomal symbiotic gene transfer in the environment. Proc. Natl. Acad. Sci. U.S.A. 92: 8985-8989.

Taylor, N.L., and Smith, R.R. 1998. Kura clover (Trifolium ambiguum M.B.) breeding, culture, and utilization. Adv. Agron. 63: $153-178$. 
Copyright $\odot 2003$ EBSCO Publishing 